\title{
DETERMINATION OF 17 ELEMENTS IN FREE-RANGE HEN EGGS WITH ICP-MS
}

\author{
KILIÇ Altun, S. ${ }^{*}-$ PAKSOY, N. ${ }^{2}-$ Dinç, H. ${ }^{3}-$ DuRMaZ, H. ${ }^{1}$ \\ ${ }^{1}$ Harran University, Veterinary Faculty, Department of Food Hygiene and Technology \\ 63200 Şanliurfa, Turkey \\ ${ }^{2}$ Harran University, Veterinary Faculty, Department of Biochemistry, 63200 Şanluurfa, Turkey \\ ${ }^{3}$ Harran University, Veterinary Faculty, Department of Pharmacology and Toxicology \\ 63200 Şanlıurfa, Turkey \\ *Corresponding author \\ e-mail: skilicaltun@harran.edu.tr; phone: +90-414-318-2676
}

(Received $27^{\text {th }}$ Feb 2019; accepted $15^{\text {th }}$ May 2019)

\begin{abstract}
The egg is a widely consumed food material with the higher nutritional value obtained from poultry. It contains almost all the nutrients needed by metabolism, therefore, the biological value of an egg is high. The aim of this study is to determine the levels of eighteen elements in free-range hen eggs. Eggs $(n=217)$ were collected from February 2017 to September 2017 in the spring, summer and autumn seasons from towns near the Syrian border. The ICP-MS method was used to determine the $\mathrm{Na}, \mathrm{Mg}, \mathrm{K}$, $\mathrm{Ca}, \mathrm{Cr}, \mathrm{Mn}, \mathrm{Fe}, \mathrm{Co}, \mathrm{Ni}, \mathrm{Cu}, \mathrm{Zn}, \mathrm{Se}, \mathrm{Ti}, \mathrm{As}, \mathrm{Cd}, \mathrm{Tl}$ and $\mathrm{Pb}$ elements levels in the study. The most abundant elements were $\mathrm{Na}$ and $\mathrm{K}$ ranging between $248.12-7755 \mathrm{mg} / \mathrm{kg}$ and $80.25-4235 \mathrm{mg} / \mathrm{kg}$, respectively. When the element levels of the free-range hen egg samples were examined, it was seen that there was a statistical difference between the seasons while the samples were contaminated with As on an average of $1131.25 \mu \mathrm{g} / \mathrm{kg}$ when the toxic element levels were examined. It was concluded that the element content of free-range hen eggs produced in this region was affected by seasonal changes.
\end{abstract}

Keywords: free-range hen eggs, ICP-MS, macro element, micro element, toxic element

\section{Introduction}

Occupation and income status of a society influences nutritional habits and thereby human health. Due to easily accessible, the widely available food source of hen eggs, which are basic food ingredients, consumed a lot in the worldwide. Hen egg has important nutritional value and contributes significantly to a healthy diet with its' highquality proteins, vitamins, fats, and minerals (Domingo, 2014). A medium-sized egg includes $78 \mathrm{kcal}$, consisting of $6.5 \mathrm{~g}$ of protein, $2.3 \mathrm{~g}$ monounsaturated fat on an average. Most of the lipids of the egg are in the form of lipoproteins found in egg yolk as well as proteins located in all parts of the egg (Kovacs-Nolan et al., 2005; Domingo, 2014). It also includes dietary cholesterol, unsaturated fatty acids, and minerals (Fernandez, 2012). In continents surveyed by Food and Agriculture Organization of the United Nations, per capita egg consumption in 2009 varied from $2.3 \mathrm{~kg}$ in Africa to $12.7 \mathrm{~kg}$ in Europe (FAO, 2012). According to the Central Association of Egg Producers of Turkey (YUM-BIR), Turks consume 200 chicken eggs per person per year (YUMBIR, 2015).

In recent years consumers began to prefer free-range hen eggs although the yolk color of free-range eggs was lower than that of battery-reared hen eggs (Kucukkoyuncu et al., 2017). Instead of battery-reared system eggs owing to the common wisdom that free-range hen eggs have preferable nutritional quality. In the free-range system, hens 
have opportunity pasture foraging in around. A close relationship with the environment may cause to be exposed to contaminants (Van Overmeire et al., 2006). And even freerange hen eggs are expected good bio-indicators of the contaminants of the environment in where the hen's pasture (Chang et al., 1989). Despite this well- known view, homeproduced foods like free-range hen eggs are not analyzed to any convenience check by a routine program. Monitoring the levels of the macro, trace, and potentially toxic elements are one of the aspects of the food and also environmental quality. Macro and trace elements are found naturally and essential for throughout life (Esposito et al., 2016). But toxic elements such as $\mathrm{Pb}, \mathrm{Cd}$, As known to be toxic and have maximum limits by European Commission in some foods but not for eggs (European Commission Regulation, EC No 1881, 2006). The European Food Safety Authority has reported that the environmental pollutants such as toxic element detected in free-range hen eggs that pasture outdoors and more exposed to environmental contamination were higher than those detected in battery-reared hen eggs (EFSA Scientific Report-update of the monitoring of levels of dioxins and PCBs in food and feed, 2012). Actually, a close relationship with the soil identifies higher levels of $\mathrm{Co}, \mathrm{Zn}, \mathrm{Pb}$ in free-range hen eggs (de Freitas et al., 2013).

Şanliurfa is located along the Syrian border and has four districts on the borderline. These are; Akçakale, Birecik, Harran, and Suruç. In these districts, that they are close of the Syrian war which is ongoing for a long time, the possible transition of toxic element contaminants from the environment to the local consumers and even to the food chain are not existing. The design of this paper focuses on the content of thirteen essential elements ( $\mathrm{Na}, \mathrm{Mg}, \mathrm{K}, \mathrm{Ca}, \mathrm{Cr}, \mathrm{Mn}, \mathrm{Fe}, \mathrm{Co}, \mathrm{Cu}, \mathrm{Zn}, \mathrm{Se}, \mathrm{Ni}, \mathrm{Ti}$ ) and four toxic elements (As, $\mathrm{Pb}, \mathrm{Tl}, \mathrm{Cd}$ ) in fresh eggs of free-range hen eggs which should be bio-indicator of pollution. To the best of our knowledge, this study provides the first seasonal variation of elements in free-range hen eggs worldwide. The aims were for (1) an evaluation of concentrations of elements, (2) a vision of seasonal variations, and (3) indication of cautious risk affects.

\section{Material and Methods}

\section{Samples}

A total of 217 fresh eggs from free ranged hens were used as study material. The samples were separated depending on the seasonal variations as

i) 60 eggs collected in the spring season.

ii) 73 eggs collected in the summer season.

iii) 84 eggs collected in the autumn season.

The samples were collected from home producers from Akçakale, Birecik, Harran, Suruç between March to October 2017 as shown in Figure 1. They were transported to the laboratory and stored at $4^{\circ} \mathrm{C}$ until analyses.

\section{Sample preparation and analytical procedures}

Egg samples were homogenized by taking into $50 \mathrm{ml}$ sterile falcon tubes. Whole equipment was previously kept for one night in $10 \% \mathrm{HNO}_{3}$ and then washed with ultrapure water to eliminate possible contamination of elements. One $g$ of the homogenized egg samples were mineralized acid digestion with $6 \mathrm{ml} \mathrm{HNO} 365 \%(\mathrm{v} / \mathrm{v})$ (Merck, Germany) and $2 \mathrm{ml} \mathrm{H}_{2} \mathrm{O}_{2} 30 \%$ (v/v) (Merck, Germany) in PTFE vessels of 
Mars Xpress (CEM Corporation) microwave system as described in the literature (Esposito et al., 2016). Subsamples were treated as the following procedure; up to $120^{\circ} \mathrm{C}$ for $7 \mathrm{~min} 1600 \mathrm{~W}$ and constant $5 \mathrm{~min}$, up to $160^{\circ} \mathrm{C}$ for $5 \mathrm{~min} 1600 \mathrm{~W}$ and constant $5 \mathrm{~min}$, up to $210^{\circ} \mathrm{C}$ for $20 \mathrm{~min} 1600 \mathrm{~W}$ and constant $5 \mathrm{~min}$. The same procedure was done for every blank sample (1 $\mathrm{ml}$ ultrapure water). After the cooling stage to room temperature $\left(22-23^{\circ} \mathrm{C}\right)$, the subsamples were diluted to $50 \mathrm{ml}$ with ultrapure water (MES MP Mini pure, Turkey).

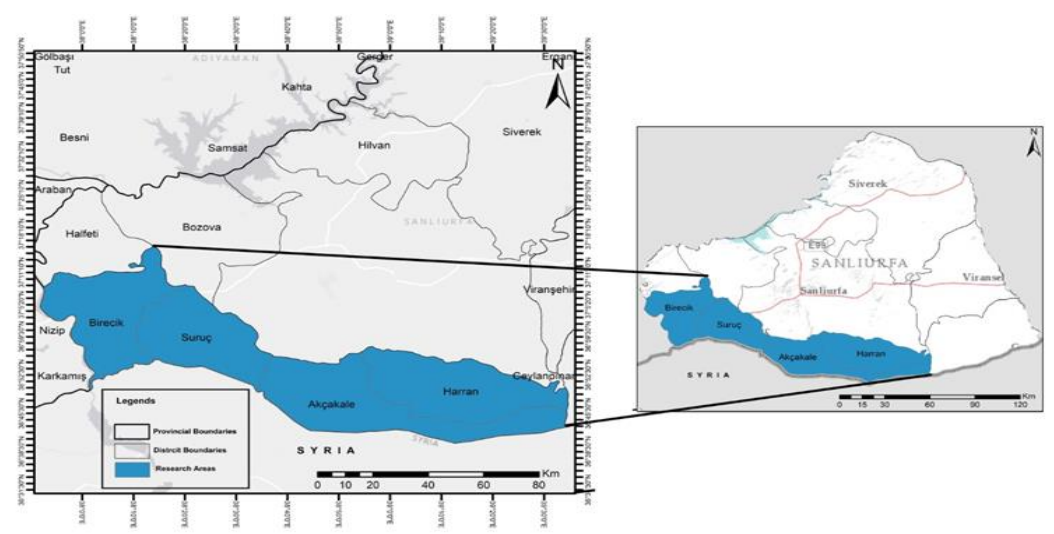

Figure 1. Map of the study area

Elemental analyses were done by Inductively Coupled Plasma Mass Spectrometer (ICP-MS) (Agilent 7500ce with an Octopole Reaction System) equipped with a nebulizer (Agilent, Japan), autosampler (Cetac ASX-520), and spray chamber.

All analytical method were performed according to the method of UNI EN 15763: 2010 preferably modified. The following isotopes were measured: ${ }^{23} \mathrm{Na}^{+},{ }^{24} \mathrm{Mg}^{+},{ }^{39} \mathrm{~K}^{+}$, ${ }^{44} \mathrm{Ca}^{+},{ }^{52} \mathrm{Cr}^{+},{ }^{55} \mathrm{Mn}^{+},{ }^{56} \mathrm{Fe}^{+},{ }^{59} \mathrm{Co}^{+},{ }^{63} \mathrm{Cu}^{+},{ }^{66} \mathrm{Zn}^{+},{ }^{78} \mathrm{Se}^{+},{ }^{75} \mathrm{As}^{+},{ }^{206} \mathrm{~Pb}^{+},{ }^{60} \mathrm{Ni}^{+},{ }^{48} \mathrm{Ti}^{+},{ }^{205} \mathrm{Tl}^{+}$, ${ }^{111} \mathrm{Cd}^{+}$.

Quality controls were assured to confirm the accuracy of the analytical procedure with the reference materials (NIST SRM 1515 Apple Leaves). The limit of detection and quantification were calculated as three and ten times.

Analyses of certified reference material allowed an assessment of accuracy and precision over a range of element concentrations. Certified values indicated that monitored levels correlated well with certified levels as shown in Table 1.

\section{Statistical Analysis}

For testing the normality of the data, the Shapiro-Wilk test was performed. In order to compare normal non-dispersive variables in more than two independent groups, Kruskal Wallis and All Pairwise Multiple Comparison tests were used. Spearman Rank Correlation Coefficient was used in testing the relations between numerical variables. For descriptive statistics, mean \pm standard deviation values for numerical variables are given. Values of $\mathrm{P}<0.05$ was considered as statistically significant. All statistical analyses were performed in order to verify the existence or not of significant differences between the samples. SPSS for Windows version 24.0 package program (SPSS Inc., Chicago, USA) was used for statistical analysis. When the concentration of the element was below the limit of quantification (LOQ) that value did not participate in the statistic. 
Table 1. Element concentrations in certified reference material (NIST SRM 1515 Apple Leaves)

\begin{tabular}{c|c|c|c}
\hline Element & Certified data $\mathbf{( m g / k g )}$ & Our data $\mathbf{( m g} / \mathbf{k g})$ & Recovery $(\%)$ \\
\hline $\mathrm{Na}$ & 10.0 & 9.96 & 99.6 \\
$\mathrm{Mg}$ & 10.0 & 9.95 & 99.5 \\
$\mathrm{~K}$ & 10.0 & 9.98 & 99.8 \\
$\mathrm{Ca}$ & 10.0 & 10.2 & 102 \\
$\mathrm{Cr}$ & 10.0 & 9.95 & 99.5 \\
$\mathrm{Mn}$ & 10.0 & 9.90 & 99.0 \\
$\mathrm{Fe}$ & 10.0 & 10.4 & 104 \\
$\mathrm{Co}$ & 10.0 & 9.93 & 99.3 \\
$\mathrm{Cu}$ & 10.0 & 9.99 & 99.9 \\
$\mathrm{Zn}$ & 10.0 & 9.97 & 99.7 \\
$\mathrm{Se}$ & 10.0 & 9.96 & 99.6 \\
$\mathrm{Ti}$ & 10.0 & 10.1 & 101 \\
$\mathrm{As}$ & 10.0 & 9.97 & 99.7 \\
$\mathrm{~Pb}$ & 10.0 & 10.3 & 103 \\
$\mathrm{Ni}$ & 10.0 & 10.4 & 104 \\
$\mathrm{Tl}$ & 10.0 & 9.95 & 99.5 \\
$\mathrm{Cd}$ & 10.0 & 10.5 & 105 \\
\hline
\end{tabular}

\section{Results and Discussion}

The concentration of Sodium, Magnesium, Potassium, Calcium, Chromium, Manganese, Iron, Cobalt, Copper, Zinc, Selenium, Arsenic, Lead, Nickel, Titanium, Talium, Cadmium in the egg samples are listed in Table 2, which reports mean and standard deviation in different seasons and Table 3 reports median and quartiles of freerange hen eggs. Box plot analyses of groups of data was shown in Figure 2.

Table 2. Comparison of concentrations of elements between seasons

\begin{tabular}{c|c|c|c|c|c|c}
\hline Element & $\begin{array}{c}\text { Positive } \\
\text { sample (n) }\end{array}$ & $\begin{array}{c}\text { Spring } \\
\text { (Mean } \pm \text { SD) }\end{array}$ & $\begin{array}{c}\text { Positive } \\
\text { sample (n) }\end{array}$ & $\begin{array}{c}\text { Summer } \\
\text { (Mean } \pm \text { SD) }\end{array}$ & $\begin{array}{c}\text { Positive } \\
\text { sample (n) }\end{array}$ & $\begin{array}{c}\text { Autumn } \\
\text { (Mean } \pm \text { SD) }\end{array}$ \\
\hline $\mathrm{Na}(\mathrm{mg} / \mathrm{kg})$ & 60 & $1278.08 \pm 324.27$ & 73 & $4329.86 \pm 1460.72$ & 84 & $1707.73 \pm 384.32$ \\
$\mathrm{Mg}(\mathrm{mg} / \mathrm{kg})$ & 60 & $246.15 \pm 31.44$ & 73 & $143.54 \pm 25.57$ & 84 & $157.76 \pm 17.47$ \\
$\mathrm{~K}(\mathrm{mg} / \mathrm{kg})$ & 60 & $1035.92 \pm 342.37$ & 73 & $1953.67 \pm 775.17$ & 84 & $1964.9 \pm 437.86$ \\
$\mathrm{Ca}(\mathrm{mg} / \mathrm{kg})$ & 60 & $1067.33 \pm 219.75$ & 73 & $490.53 \pm 167.6$ & 84 & $560.54 \pm 111.96$ \\
$\mathrm{Cr}(\mu \mathrm{g} / \mathrm{kg})$ & 13 & $543.92 \pm 35.38$ & & $<\mathrm{LOQ}$ & & $<\mathrm{LOQ}$ \\
$\mathrm{Mn}(\mu \mathrm{g} / \mathrm{kg})$ & 34 & $709.41 \pm 152.94$ & & $<\mathrm{LOQ}$ & 6 & $576.16 \pm 35.38$ \\
$\mathrm{Fe}(\mathrm{mg} / \mathrm{kg})$ & 60 & $39.9 \pm 12.79$ & 73 & $112.01 \pm 25.76$ & 84 & $45.65 \pm 8.88$ \\
$\mathrm{Co}(\mu \mathrm{g} / \mathrm{kg})$ & & $<\mathrm{LOQ}$ & & $<\mathrm{LOQ}$ & & $<\mathrm{LOQ}$ \\
$\mathrm{Cu}(\mu \mathrm{g} / \mathrm{kg})$ & 14 & $974.12 \pm 850.27$ & 73 & $9904.66 \pm 4004.7$ & 84 & $2012.95 \pm 365.29$ \\
$\mathrm{Zn}(\mathrm{mg} / \mathrm{kg})$ & 60 & $32.34 \pm 7.44$ & 60 & $11.80 \pm 6.50$ & 84 & $22.77 \pm 4.59$ \\
$\mathrm{Se}(\mu \mathrm{g} / \mathrm{kg})$ & 60 & $7354.92 \pm 2972.93$ & 38 & $9875.39 \pm 4522.55$ & 84 & $11834.66 \pm 3624.58$ \\
$\mathrm{Ti}(\mu \mathrm{g} / \mathrm{kg})$ & 60 & $3940.1 \pm 578.65$ & 35 & $3021.57 \pm 353.47$ & 84 & $2125.68 \pm 247.91$ \\
$\mathrm{As}(\mu \mathrm{g} / \mathrm{kg})$ & 3 & $841.66 \pm 263.45$ & 1 & 2545 & 4 & $990.25 \pm 70.35$ \\
$\mathrm{~Pb}(\mu \mathrm{g} / \mathrm{kg})$ & & $<\mathrm{LOQ}$ & & $<\mathrm{LOQ}$ & & $<\mathrm{LOQ}$ \\
$\mathrm{Ni}(\mu \mathrm{g} / \mathrm{kg})$ & 20 & $140.25 \pm 109.45$ & & $<\mathrm{LOQ}$ & & $<\mathrm{LOQ}$ \\
$\mathrm{Tl}(\mu \mathrm{g} / \mathrm{kg})$ & & $<\mathrm{LOQ}$ & & $<\mathrm{LOQ}$ & & $<\mathrm{LOQ}$ \\
$\mathrm{Cd}(\mu \mathrm{g} / \mathrm{kg})$ & & $<\mathrm{LOQ}$ & & $<\mathrm{LOQ}$ & & $<\mathrm{LOQ}$ \\
\hline
\end{tabular}


Table 3. Values of median, 25th, and 75th variance for essential elements in free-range hen eggs

\begin{tabular}{c|ccc|ccc|ccc}
\hline & \multicolumn{3}{|c|}{ Spring } & \multicolumn{3}{c|}{ Summer } & \multicolumn{3}{c}{ Autumn } \\
\cline { 2 - 10 } & Quartile 1 & Median & Quartile 3 & Quartile 1 & Median & Quartile 3 & Quartile 1 & Median & Quartile 3 \\
\hline $\mathrm{Na}(\mathrm{mg} / \mathrm{kg})$ & 1068.76 & 1234.68 & 1417.49 & 3202.50 & 4137.50 & 5655.00 & 1510.40 & 1763.60 & 1954.40 \\
$\mathrm{Mg}(\mathrm{mg} / \mathrm{kg})$ & 223.07 & 241.39 & 262.26 & 126.35 & 144.35 & 158.80 & 147.33 & 157.53 & 166.73 \\
$\mathrm{~K}(\mathrm{mg} / \mathrm{kg})$ & 846.30 & 997.43 & 1179.55 & 1549.00 & 1848.00 & 2502.50 & 1831.00 & 2020.00 & 2177.50 \\
$\mathrm{Ca}(\mathrm{mg} / \mathrm{kg})$ & 878.75 & 1095.00 & 1217.25 & 360.25 & 489.25 & 611.50 & 522.00 & 558.00 & 601.00 \\
$\mathrm{Fe}(\mathrm{mg} / \mathrm{kg})$ & 32.89 & 39.12 & 46.82 & 93.15 & 104.68 & 121.53 & 39.74 & 45.32 & 50.10 \\
$\mathrm{Cu}(\mu \mathrm{g} / \mathrm{kg})$ & 137.50 & 824.05 & 1895.85 & 7290.00 & 9027.50 & 13525.00 & 1796.00 & 2026.25 & 2251.50 \\
$\mathrm{Zn}(\mathrm{mg} / \mathrm{kg})$ & 26.80 & 33.01 & 36.86 & 6.55 & 11.19 & 15.03 & 20.62 & 22.447 .50 & 25.45 \\
$\mathrm{Se}(\mu \mathrm{g} / \mathrm{kg})$ & 5048.30 & 6522.85 & 8820.85 & 6510.00 & 8668.75 & 12702.50 & 9935.00 & 11505.00 & 14555.00 \\
\hline
\end{tabular}
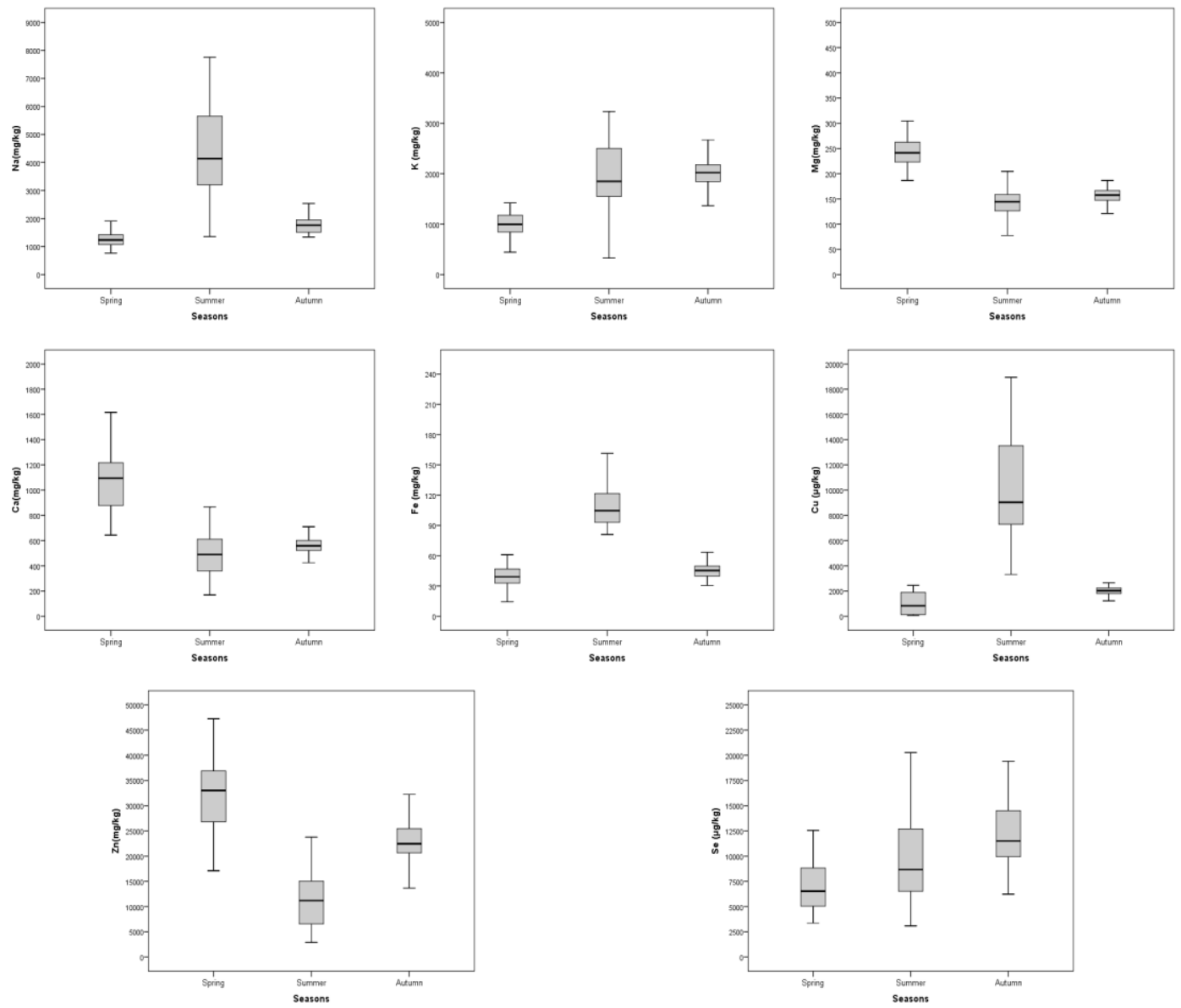

Figure 2. Box plot of essential elements in free-range hen eggs

In the present study the sodium content of free-range hen eggs showed an average level of $1278.08 \mathrm{mg} / \mathrm{kg}$ in the spring season; this is relatively low when compared with the mean level $(1707.73 \mathrm{mg} / \mathrm{kg})$ in the autumn season and also very low when compared with the mean level $(4329.86 \mathrm{mg} / \mathrm{kg})$ in the summer season. Table 4 shows the 
comparison of the levels of elements reported in the different samples of home-grown hen and free-range hen eggs with previous literature. In the literature, the sodium content of eggs showed a mean level of $1149 \mathrm{mg} / \mathrm{kg}$; this is lowly especially compared with the present study (Rubio et al., 2017).

Magnesium concentration of spring, summer, and autumn seasons in free-range hen eggs showed mean levels of $246.15,143.54,157.76 \mathrm{mg} / \mathrm{kg}$, respectively. In the literature, a lower value have been reported in Canary Islands $(87.5 \mathrm{mg} / \mathrm{kg})$, while value as high as has been found in home-produced eggs from Brazil $(674 \mathrm{mg} / \mathrm{kg}$ ) (de Freitas et al., 2013).

The average levels of potassium detected in free-range hen eggs were $1034.92 \mathrm{mg} / \mathrm{kg}$ in spring, $1953.67 \mathrm{mg} / \mathrm{kg}$ in summer, and $1964.9 \mathrm{mg} / \mathrm{kg}$ in the autumn season. These values are high, especially when compared with the reported data in the literature (Rubio et al., 2017, 2018).

These latter tables report calcium concentrations of $1067.33 \mathrm{mg} / \mathrm{kg}$ in spring season while the value is higher than both summer $(490.53 \mathrm{mg} / \mathrm{kg})$ and autumn $(560.54 \mathrm{mg} / \mathrm{kg})$ seasons. The concentrations in our samples were also comparable to that reported in free-range hens egg from the Island of Tenerife with a mean level of $231 \mathrm{mg} / \mathrm{kg}$ (Rubio et al., 2018).

The average level of chromium in the spring season $(543.92 \mu \mathrm{g} / \mathrm{kg})$ is much higher than that detected in both summer $(<\mathrm{LOQ})$ and autumn $(<\mathrm{LOQ})$ season. In the spring, due to the fact that the chromium element is detected in egg samples, agricultural activities in the region are intense and pesticides and foliar fertilizers are generally applied in spring.

The manganese is one of the most abundant elements in the earth crust. The manganese mean content in the spring season $(709.41 \mu \mathrm{g} / \mathrm{kg})$ was higher than the mean content in autumn season $(576.16 \mu \mathrm{g} / \mathrm{kg})$ and in free-range hen eggs in United Kingdom $(0.277 \mathrm{mg} / \mathrm{kg}$ ) (Siddiqui et al., 2011). The iron mean content in the spring season $(39.9 \mathrm{mg} / \mathrm{kg})$ was lower than the values found in summer season $(112.01 \mathrm{mg} / \mathrm{kg}) \mathrm{but}$ similar to that analyzed in autumn season $(45.65 \mathrm{mg} / \mathrm{kg})$. The mean concentration of iron determined in free-range hen eggs proved to be far higher than the levels reported in eggs in the Island of Tenerife $(7.62 \mathrm{mg} / \mathrm{kg}$ ) (Rubio et al., 2018) and parallel with eggs in Brazil $(114 \mu \mathrm{g} / \mathrm{g})$ (de Freitas et al., 2013).

In the present study, the average level of copper was significantly increased from 974.12 to $9904.66 \mu \mathrm{g} / \mathrm{kg}$ between spring season to summer season afterward in the autumn season the mean copper content was $2012.95 \mu \mathrm{g} / \mathrm{kg}$. The change rule of the concentration of copper was similar to iron.

The average concentration of Zinc in free-range hen eggs in spring season $(32.34 \mathrm{mg} / \mathrm{kg})$ was significantly higher than both summer $(11.80 \mathrm{mg} / \mathrm{kg})$ and autumn $(22.77 \mathrm{mg} / \mathrm{kg}$ ) season and was 10-fold higher than reported in fresh cage-reared hens eggs from Canary Islands (Rubio et al., 2017).

The average level of selenium in free-range hens eggs was increased from 7354.92 to 11834.66 between spring to autumn season and marginally higher than found in eggs from residential backyards in Italy (Esposito et al., 2016).

Arsenic is a micropollutant which can be easily detected in the soil, water, fertilizer, and industrial wastes. Long term exposures, arsenic is accumulated in metabolism and should because chronic diseases (Hashemi et al., 2018). The mean concentration of arsenic in free-range hen eggs was $841.66 \mu \mathrm{g} / \mathrm{kg}$ in the spring season, $2545 \mu \mathrm{g} / \mathrm{kg}$ in the summer season, and $990.25 \mu \mathrm{g} / \mathrm{kg}$ in the autumn season. 
Table 4. Comparison of the levels of elements reported in the different samples of home-grown hen and free-range hen eggs

\begin{tabular}{|c|c|c|c|c|c|c|c|c|c|c|c|}
\hline Element & $\begin{array}{l}\text { Rubio et al. } \\
\text { (2017) }\end{array}$ & $\begin{array}{c}\text { Rubio et al. } \\
\text { (2018) }\end{array}$ & $\begin{array}{l}\text { Esposito et } \\
\text { al. (2016) }\end{array}$ & $\begin{array}{c}\text { Grace and } \\
\text { MacFarlane } \\
\text { (2016) }\end{array}$ & $\begin{array}{c}\text { De Freitas et al. } \\
(\mathbf{2 0 1 3})\end{array}$ & $\begin{array}{c}\text { Van } \\
\text { Overmeire } \\
\text { et al. (2006) }\end{array}$ & $\begin{array}{c}\text { Fakayode } \\
\text { and Olu- } \\
\text { Owolabi } \\
(2003)\end{array}$ & $\begin{array}{l}\text { Hashemi } \\
\text { et al. } \\
(2018)\end{array}$ & $\begin{array}{l}\text { This study } \\
\text { Spring }\end{array}$ & $\begin{array}{l}\text { This study } \\
\text { Summer }\end{array}$ & $\begin{array}{l}\text { This study } \\
\text { Autumn }\end{array}$ \\
\hline $\begin{array}{c}\mathrm{Na} \\
(\mathrm{mg} / \mathrm{kg})\end{array}$ & $1149 \pm 96.2$ & $1290 \pm 154$ & & & & & & & $1278.08 \pm 324.27$ & $4329.86 \pm 1460.72$ & $1707.73 \pm 384.32$ \\
\hline $\begin{array}{c}\mathrm{Mg} \\
(\mathrm{mg} / \mathrm{kg})\end{array}$ & $87.5 \pm 26.1$ & $103 \pm 13$ & & & $674 \pm 138$ & & & & $246.15 \pm 31.44$ & $143.54 \pm 25.57$ & $157.76 \pm 17.47$ \\
\hline $\mathrm{K}(\mathrm{mg} / \mathrm{kg})$ & $491 \pm 217$ & $712 \pm 135$ & & & & & & & $1035.92 \pm 342.37$ & $1953.67 \pm 775.17$ & $1964.9 \pm 437.86$ \\
\hline $\mathrm{Ca}(\mathrm{mg} / \mathrm{kg})$ & $174 \pm 83.3$ & $231 \pm 56$ & & & & & & & $1067.33 \pm 219.75$ & $490.53 \pm 167.6$ & $560.54 \pm 111.96$ \\
\hline $\mathrm{Cr}(\mu \mathrm{g} / \mathrm{kg})$ & $170 \pm 240$ & $50.0 \pm 90.0$ & $8.0 \pm 9.0$ & & & & & 1621 & $543.92 \pm 35.38$ & $<$ LOQ & $<\mathrm{LOQ}$ \\
\hline$\underset{(\mu \mathrm{gn} / \mathrm{kg})}{\mathrm{Mn}}$ & $100 \pm 110$ & $140 \pm 70$ & $360 \pm 142$ & & $1500 \pm 600$ & 313.98 & & & $709.41 \pm 152.94$ & $<\mathrm{LOQ}$ & $576.16 \pm 35.38$ \\
\hline $\mathrm{Fe}(\mathrm{mg} / \mathrm{kg})$ & $5.49 \pm 4.10$ & $7.62 \pm 2.7$ & & & $114 \pm 30$ & & 23.20 & & $39.9 \pm 12.79$ & $112.01 \pm 25.76$ & $45.65 \pm 8.88$ \\
\hline $\mathrm{Co}(\mu \mathrm{g} / \mathrm{kg})$ & $<$ LOQ & $<$ LOQ & $4.0 \pm 2.0$ & & $19100 \pm 12500$ & 5.15 & 10 & & $<$ LOQ & $<$ LOQ & $<\mathrm{LOQ}$ \\
\hline $\mathrm{Cu}(\mu \mathrm{g} / \mathrm{kg})$ & $2220 \pm 1100$ & $1780 \pm 780$ & $679 \pm 128$ & 750 & $2900 \pm 500$ & 603.64 & 780 & & $974.12 \pm 850.27$ & $9904.66 \pm 4004.7$ & $2012.95 \pm 365.29$ \\
\hline $\mathrm{Zn}(\mathrm{mg} / \mathrm{kg})$ & $3.37 \pm 1.73$ & $5.03 \pm 1.4$ & $15.75 \pm 4.05$ & 11.3 & $65.3 \pm 20.3$ & 11.543 & 13.75 & & $32.34 \pm 7.44$ & $11.80 \pm 6.50$ & $22.77 \pm 4.59$ \\
\hline $\operatorname{Se}(\mu \mathrm{g} / \mathrm{kg})$ & & & $313 \pm 147$ & & $600 \pm 200$ & 272.97 & & & $7354.92 \pm 2972.93$ & $9875.3 \pm 4522.5$ & $11834.6 \pm 3624.5$ \\
\hline $\mathrm{Ti}(\mu \mathrm{g} / \mathrm{kg})$ & & & & & & & & & $3940.1 \pm 578.65$ & $3021.5 \pm 353.4$ & $2125.6 \pm 247.9$ \\
\hline As $(\mu \mathrm{g} / \mathrm{kg})$ & & & $7.0 \pm 4.0$ & 30 & $21.5 \pm 8.5$ & 15.95 & & & $841.66 \pm 263.45$ & 2545 & $990.2 \pm 70.3$ \\
\hline $\mathrm{Pb}(\mu \mathrm{g} / \mathrm{kg})$ & $20 \pm 20$ & $30 \pm 20$ & $19 \pm 28$ & 90 & $89 \pm 245$ & 68.56 & 590 & & $<$ LOQ & $<$ LOQ & $<\mathrm{LOQ}$ \\
\hline $\mathrm{Ni}(\mu \mathrm{g} / \mathrm{kg})$ & $50 \pm 30$ & $30 \pm 20$ & $96 \pm 97$ & & & 36.58 & 30 & & $140.25 \pm 109.45$ & $<$ LOQ & $<$ LOQ \\
\hline $\mathrm{Tl}(\mu \mathrm{g} / \mathrm{kg})$ & & & $10 \pm 22$ & & & 0.69 & & & $<$ LOQ & $<$ LOQ & $<$ LOQ \\
\hline $\mathrm{Cd}(\mu \mathrm{g} / \mathrm{kg})$ & $<$ LOQ & $<$ LOQ & $3 \pm 3$ & 1 & $0.6 \pm 0.5$ & 0.53 & 70 & 13 & $<$ LOQ & $<$ LOQ & $<$ LOQ \\
\hline
\end{tabular}


The reported concentrations of arsenic in egg samples from Italy (Esposito et al., 2016), Australia (Grace and MacFarlane, 2016), Brazil (de Freitas et al., 2013) were 7.0, 30 , and $21.5 \mu \mathrm{g} / \mathrm{kg}$, respectively. The finding of this study is very high than the reported concentrations of arsenic in egg samples from different countries.

The mean value of nickel from Canary Island (Rubio et al., 2018), Italy (Esposito et al., 2016), and Turkey (Uluözlü et al., 2009) were 30, 96, and $90 \mu \mathrm{g} / \mathrm{kg}$, respectively. These levels are lower than our study $(140.25 \mu \mathrm{g} / \mathrm{kg})$.

\section{Element content in the free-range hen eggs in the spring season}

The mean concentration and standard deviation of each element analyzed in the spring season are shown in Table 5. Sodium $(1278.08 \mathrm{mg} / \mathrm{kg}$ ) was the most abundant macro-element analyzed in the highest proportion in free-range hen egg samples, followed by $\mathrm{Ca}>\mathrm{K}>\mathrm{Mg}$.

Table 5. Descriptive statistics of essential elements for the spring season

\begin{tabular}{c|c|c|c|c}
\hline Elements & Akçakale & Birecik & Harran & Suruç \\
\hline $\mathrm{Na}(\mathrm{mg} / \mathrm{kg})$ & $1280.7 \pm 152.97$ & $1440.38 \pm 435.26$ & $1244.67 \pm 266.59$ & $1146.58 \pm 333.55$ \\
$\mathrm{Mg}(\mathrm{mg} / \mathrm{kg})$ & $236.3 \pm 25.72$ & $254.7 \pm 33.09$ & $248.43 \pm 39.06$ & $245.17 \pm 26.33$ \\
$\mathrm{~K}(\mathrm{mg} / \mathrm{kg})$ & $1073.22 \pm 167.25$ & $1378.47 \pm 419.25$ & $936.3 \pm 137.13$ & $755.68 \pm 222.36$ \\
$\mathrm{Ca}(\mathrm{mg} / \mathrm{kg})$ & $979.97 \pm 211.01$ & $1029.67 \pm 191.62$ & $1074.1 \pm 210.94$ & $1185.6 \pm 230.29$ \\
$\mathrm{Fe}(\mathrm{mg} / \mathrm{kg})$ & $39.27 \pm 11.72$ & $41.86 \pm 9.36$ & $41.22 \pm 18.52$ & $37.26 \pm 10.37$ \\
$\mathrm{Cu}(\mu \mathrm{g} / \mathrm{kg})$ & $104.73 \pm 46.35$ & $929.56 \pm 796.22$ & $719.11 \pm 512.22$ & $1729.1 \pm 1058.9$ \\
$\mathrm{Zn}(\mathrm{mg} / \mathrm{kg})$ & $28.90 \pm 6.85$ & $31.06 \pm 5.28$ & $32.18 \pm 7.15$ & $37.21 \pm 8.22$ \\
$\mathrm{Se}(\mu \mathrm{g} / \mathrm{kg})$ & $7426.73 \pm 1208.47$ & $11655.05 \pm 1955.3$ & $5761.96 \pm 743.91$ & $4575.93 \pm 774.25$ \\
\hline
\end{tabular}

The major trace element found in egg samples was selenium $(7354.92 \mu \mathrm{g} / \mathrm{kg})$, followed by $\mathrm{Cu}>\mathrm{Mn}>\mathrm{Ti}>\mathrm{Cr}>\mathrm{Ni}>\mathrm{Fe}>\mathrm{Zn}>\mathrm{Co}$. Arsenic $(841.66 \mu \mathrm{g} / \mathrm{kg})$ was the most abundant toxic element found in three free-range hen eggs; $\mathrm{Pb}, \mathrm{Tl}, \mathrm{Cd}$ levels were below the limit of quantification in all samples in the spring season.

\section{Element content in the free-range hen eggs in the summer season}

The mean concentration and standard deviation of each element analyzed in the summer season are shown in Table 6. The most abundant macroelement in the freerange hen eggs was sodium $(4329.86 \mathrm{mg} / \mathrm{kg}$ ), followed by $\mathrm{K}>\mathrm{Ca}>\mathrm{Mg}$. As for the trace elements, copper $(9904.66 \mu \mathrm{g} / \mathrm{kg})$ was the most notable in the egg samples, followed by $\mathrm{Se}>\mathrm{Ti}>\mathrm{Fe}>\mathrm{Zn}$. The $\mathrm{Cr}, \mathrm{Mn}, \mathrm{Co}$ and Ni levels were below the limit of quantification in all samples in the summer season. The detected levels of $\mathrm{Co}$ and $\mathrm{Cd}$ were below the quantification limit. Arsenic $(2545 \mu \mathrm{g} / \mathrm{kg})$ was the most abundant toxic element found in 1 free-range hen egg; $\mathrm{Pb}, \mathrm{Tl}, \mathrm{Cd}$ levels were below the limit of quantification in all samples in the summer season.

\section{Element content in the free-range hen eggs in the autumn season}

The mean concentration and standard deviation of each element analyzed in autumn season are shown in Table 7. Potassium $(1964.90 \mathrm{mg} / \mathrm{kg}$ ) was the most abundant macroelement analyzed in the highest proportion in egg samples, followed by $\mathrm{Na}>\mathrm{Ca}>\mathrm{Mg}$. The major trace element found in egg samples was selenium $(11834.66 \mu \mathrm{g} / \mathrm{kg})$, 
followed by $\mathrm{Ti}>\mathrm{Cu}>\mathrm{Mn}>\mathrm{Fe}>\mathrm{Zn}$. Co and $\mathrm{Ni}$ levels were below the limit of quantification in all samples in the autumn season. Arsenic $(990.25 \mu \mathrm{g} / \mathrm{kg})$ was the most abundant toxic element found in 4 free-range hen egg. The detected levels of $\mathrm{Pb}, \mathrm{Tl}$ and $\mathrm{Cd}$ were below the quantification limit in the autumn season.

Table 6. Descriptive statistics of essential elements for the summer season

\begin{tabular}{c|c|c|c|c}
\hline Elements & Akçakale & Birecik & Harran & Suruç \\
\hline $\mathrm{Na}(\mathrm{mg} / \mathrm{kg})$ & $4195.5 \pm 969.41$ & $5775.25 \pm 352.97$ & $4142.97 \pm 370.31$ & $2598.79 \pm 685.53$ \\
$\mathrm{Mg}(\mathrm{mg} / \mathrm{kg})$ & $155.15 \pm 19.87$ & $141.31 \pm 24.37$ & $136.66 \pm 15.39$ & $131.76 \pm 34.43$ \\
$\mathrm{~K}(\mathrm{mg} / \mathrm{kg})$ & $2006.99 \pm 385.34$ & $2707.8 \pm 562.41$ & $1764.94 \pm 229.93$ & $1071.89 \pm 579.56$ \\
$\mathrm{Ca}(\mathrm{mg} / \mathrm{kg})$ & $570.69 \pm 177.35$ & $463.68 \pm 111.54$ & $421.13 \pm 167.73$ & $450.91 \pm 143.39$ \\
$\mathrm{Fe}(\mathrm{mg} / \mathrm{kg})$ & $119.27 \pm 28.21$ & $129.81 \pm 20.66$ & $94.94 \pm 8.54$ & $100.51 \pm 18.19$ \\
$\mathrm{Cu}(\mu \mathrm{g} / \mathrm{kg})$ & $9568.25 \pm 2581.11$ & $14020.5 \pm 872.72$ & $9079.53 \pm 705.53$ & $5192.65 \pm 1501.68$ \\
$\mathrm{Zn}(\mathrm{mg} / \mathrm{kg})$ & $13.76 \pm 4.74$ & $8.22 \pm 3.65$ & $10.25 \pm 6.34$ & $10.38 \pm 5.373 .66$ \\
$\mathrm{Se}(\mu \mathrm{g} / \mathrm{kg})$ & $11117.12 \pm 4557.47$ & $5320 \pm 2857.78$ & $9170.77 \pm 2760.29$ & $7160 \pm 0$ \\
\hline
\end{tabular}

Table 7. Descriptive statistics of essential elements for the autumn season

\begin{tabular}{c|c|c|c|c}
\hline Element & Akçakale & Birecik & Harran & Suruç \\
\hline $\mathrm{Na}(\mathrm{mg} / \mathrm{kg})$ & $1727.77 \pm 463.76$ & $1965.72 \pm 174.47$ & $1602.34 \pm 190.34$ & $1378.14 \pm 443.87$ \\
$\mathrm{Mg}(\mathrm{mg} / \mathrm{kg})$ & $163.11 \pm 15.74$ & $159.19 \pm 15.69$ & $153.88 \pm 21.54$ & $155.26 \pm 16.49$ \\
$\mathrm{~K}(\mathrm{mg} / \mathrm{kg})$ & $1965.73 \pm 467.98$ & $2129.5 \pm 239.09$ & $2058 \pm 301.55$ & $1586.44 \pm 579.32$ \\
$\mathrm{Ca}(\mathrm{mg} / \mathrm{kg})$ & $582.32 \pm 74.77$ & $534.16 \pm 73.04$ & $584.38 \pm 133.5$ & $561.13 \pm 157.71$ \\
$\mathrm{Fe}(\mathrm{mg} / \mathrm{kg})$ & $46.45 \pm 9.19$ & $41.97 \pm 5.34$ & $50.88 \pm 8.71$ & $45.33 \pm 11$ \\
$\mathrm{Cu}(\mu \mathrm{g} / \mathrm{kg})$ & $2189.9 \pm 267.48$ & $2248.8 \pm 240.94$ & $1880.1 \pm 235.71$ & $1596.88 \pm 319.51$ \\
$\mathrm{Zn}(\mathrm{mg} / \mathrm{kg})$ & $23.10 \pm 3.385$ & $21.50 \pm 3.47$ & $23.90 \pm 7.02$ & $23.44 \pm 3.13$ \\
$\mathrm{Se}(\mu \mathrm{g} / \mathrm{kg})$ & $8765.17 \pm 2472.89$ & $10570.33 \pm 1635.91$ & $14309.25 \pm 2485.36$ & $13750.22 \pm 4963.94$ \\
\hline
\end{tabular}

\section{Correlation between elements}

Correlation between elements in free-range hen eggs samples was shown in Table 8 for the spring season, Table 9 for the summer season, and Table 10 for the autumn season.

Table 8. The correlations between the of essential elements in the spring season

\begin{tabular}{|c|c|c|c|c|c|c|c|c|}
\hline & $\mathrm{Mg}$ & $\mathbf{K}$ & $\mathrm{Ca}$ & $\mathbf{T i}$ & $\mathbf{F e}$ & $\mathrm{Cu}$ & Zn & Se \\
\hline $\mathbf{N a}$ & .236 & $.584^{* *}$ & $-.608^{* *}$ & $-.580^{* *}$ & $-.291^{*}$ & .262 & $-.684^{* * *}$ & $.397^{* * *}$ \\
\hline Mg & 1.000 & .087 & .136 & .206 & .227 & .305 & .066 & .066 \\
\hline $\mathbf{K}$ & & 1.000 & $-.338^{* * *}$ & $-.366^{* *}$ & .076 & .196 & $-.427^{* *}$ & $.732^{* *}$ \\
\hline $\mathbf{C a}$ & & & 1.000 & $.986^{* * *}$ & $.671^{* *}$ & -.196 & $.919^{* * *}$ & $-.366^{* *}$ \\
\hline $\mathbf{T i}$ & & & & 1.000 & $.644^{* * *}$ & -.103 & $.903^{* *}$ & $-.388^{* *}$ \\
\hline $\mathrm{Fe}$ & & & & & 1.000 & .134 & $.644^{* *}$ & .001 \\
\hline $\mathrm{Cu}$ & & & & & & 1.000 & -.066 & -.240 \\
\hline $\mathbf{Z n}$ & & & & & & & 1.000 & $-.428^{* *}$ \\
\hline
\end{tabular}

Notes: Spearman correlation test, ${ }^{*} \mathrm{P}<0.05,{ }^{* *} \mathrm{P}<0.01$ 
Table 9. The correlations between the essential elements in the summer season

\begin{tabular}{ccccccccc}
\hline & $\mathbf{M g}$ & $\mathbf{K}$ & $\mathbf{C a}$ & $\mathbf{T i}$ & $\mathbf{F e}$ & $\mathbf{C u}$ & $\mathbf{Z n}$ & $\mathbf{S e}$ \\
$\mathbf{N a}$ & 0.157 & $.907^{* *}$ & 0.061 & 0.014 & $.470^{* *}$ & $.964^{* *}$ & 0.028 & -0.287 \\
$\mathbf{M g}$ & 1 & 0.197 & $.525^{* *}$ & $.376^{*}$ & $.346^{* *}$ & 0.163 & $.447^{* *}$ & 0.242 \\
$\mathbf{K}$ & & 1 & 0.227 & -0.054 & $.626^{* *}$ & $.906^{* *}$ & 0.099 & -0.204 \\
$\mathbf{C a}$ & & & 1 & $.673^{* *}$ & $.562^{* *}$ & 0.171 & $.912^{* *}$ & 0.073 \\
$\mathbf{T i}$ & & & & 1 & 0.304 & 0.027 & $.621^{* *}$ & 0.403 \\
$\mathbf{F e}$ & & & & & 1 & $.533^{* *}$ & $.392^{* *}$ & 0.193 \\
$\mathbf{C u}$ & & & & & & 1 & 0.138 & -0.308 \\
$\mathbf{Z n}$ & & & & & & & & -0.115 \\
\hline
\end{tabular}

Notes: Spearman correlation test, ${ }^{*} \mathrm{P}<0.05,{ }^{* *} \mathrm{P}<0.01$

Table 10. The correlations between the elements in autumn season

\begin{tabular}{|c|c|c|c|c|c|c|c|c|}
\hline & Mg & $\mathbf{K}$ & $\mathbf{C a}$ & $\mathbf{T i}$ & $\mathrm{Fe}$ & $\mathrm{Cu}$ & Zn & Se \\
\hline $\mathbf{N a}$ & $.379^{* *}$ & $.538^{* *}$ & $-.355^{* * *}$ & .036 & -.180 & $.642^{* *}$ & $-.379^{* *}$ & $-.394^{* *}$ \\
\hline Mg & 1.000 & $.235^{*}$ & .006 & .219 & .139 & $.230^{*}$ & -.007 & -.196 \\
\hline $\mathbf{K}$ & & 1.000 & -.131 & .153 & .093 & $.532^{* *}$ & .004 & -.179 \\
\hline $\mathrm{Ca}$ & & & 1.000 & $.804^{* *}$ & $.502^{* *}$ & -.084 & $.819^{* * *}$ & .116 \\
\hline $\mathbf{T i}$ & & & & 1.000 & $.416^{* *}$ & $.319^{* *}$ & $.679^{* * *}$ & $-.224^{*}$ \\
\hline $\mathrm{Fe}$ & & & & & 1.000 & .013 & $.431^{* *}$ & .058 \\
\hline $\mathrm{Cu}$ & & & & & & 1.000 & .047 & $-.624^{* * *}$ \\
\hline $\mathbf{Z n}$ & & & & & & & 1.000 & .105 \\
\hline
\end{tabular}

Notes: Spearman correlation test, ${ }^{*} \mathrm{P}<0.05,{ }^{* *} \mathrm{P}<0.01$

In spring season, very strong correlations were detected between CaxTi, CaxZn, TixZn, and also strong correlations were detected between NaxZn, NaxCa, KxSe, $\mathrm{CaxFe}$, TixFe, FexZn as shown in Table 7. Interestingly there wasn't a correlation between elements with $\mathrm{Mg}$, so further studies required.

In the summer season, very strong correlations were detected between NaxK, $\mathrm{NaxCu}, \mathrm{CaxZn}, \mathrm{KxCu}$. Strong correlations were found between $\mathrm{KxFe}$, CaxTi, TixZn as shown in Table 9. In autumn season, very strong correlations were detected between CaxTi, CaxZn, and strong correlation between $\mathrm{NaxCu}$, TixZn, CuxSe as shown in Table 10. A correlation between CaxZn were detected in all seasons thus it means that the season is not influencing this very strong correlation.

\section{Conclusion}

In this study, the element levels of eighteen elements in the free-range hen egg samples were examined by means of ICP-MS. Free-range hen eggs are an acceptable source of essential elements, in particular, of $\mathrm{Na}, \mathrm{Mg}, \mathrm{K}, \mathrm{Ca}, \mathrm{Cu}, \mathrm{Fe}, \mathrm{Zn}$, and $\mathrm{Se}$. The presence of $\mathrm{Cr}$ in the spring season, $\mathrm{Cu}$ in the summer season and $\mathrm{Se}$ in all seasons in our samples may be related to a geographic source. Finally, the lack of data on the presence of some $\mathrm{Ti}$ in free-range hen eggs does not allow comparisons. It was seen that there was a statistical difference between the seasons so it was concluded that the 
element content of free-range hen eggs produced in this region was affected by seasonal changes.

Compilation of these data may serve to understand the element composition and to define the reference levels of macro, trace and toxic elements to be used in food safety assessments of free-range hen eggs produced in an area near the Syrian border because it was determined that eight samples of free-range hen eggs were contaminated with As on an average of $1131.25 \mu \mathrm{g} / \mathrm{kg}$ when the toxic element levels were examined. It is important to regularly monitoring the levels of toxic elements in free-range hen eggs for assessing the risk of long-term exposure.

Acknowledgements. The authors acknowledge the Harran Scientific Research Project Department of the Harran University for funding this study with the project number of 17113. This paper was presented at 1st International Veterinary Biochemistry and Clinical Biochemistry Congress which took place on April 12-15, 2018, in Hatay/Turkey.

\section{REFERENCES}

[1] Central Association of Egg Producers of Turkey (YUM-BIR) (2015): https://www.yumbir.org/UserFiles/File/Veriler2016.pdf.

[2] Chang, R., Hayward, D., Goldman, L., Harnly, M., Flattery, J., Stephens, R. (1989): Foraging animals as biomonitors for dioxin contamination. - Chemosphere 19: 481-486.

[3] de Freitas, R., Ramos, N. L., Batista, B. L., Barbosa Jr., F. (2013): Toxic and essential elements in conventional and home-produced eggs by ICP-MS analysis. - Food Additives \& Contaminants Part B Surveillance 6(1): 30-35.

[4] Domingo, J. L. (2014): Health risks of human exposure to chemical contaminants through egg consumption: a review. - Food Research International 56: 159-165.

[5] EFSA (2012): Scientific Report - update of the monitoring of levels of dioxins and PCBs in food and feed. - Europian Food Safety Authority Journal 10(7): 2832.

[6] Esposito, M., Cavallo, S., Chiaravalle, E., Miedico, O., Pellicanò, R., Rosato, G., Baldi, L. (2016): Trace elements in free-range hen eggs in the Campania region (Italy) analyzed by inductively coupled plasma mass spectrometry (ICP-MS). - Environmental Monitoring and Assessment 188(6): 326-334.

[7] European Commission Regulation (EC) No 1881 (2006). - Of 19 December 2006 setting maximum levels for certain contaminants in foodstuffs. - Official Journal of the European Union L364: 5-24.

[8] Fakayode, S. O., Olu-Owolabi, I. B. (2003): Trace metal content and estimated daily human intake from chicken eggs in Ibadan, Nigeria. - Archives of Environmental Health: An International Journal 58(4): 245-251.

[9] Fernandez, M. L. (2012): Rethinking dietary cholesterol. - Current Opinion in Clinical Nutrition \& Metabolic Care 15(2): 117-121.

[10] Food and Agriculture Organization of the United Nations (FAO) (2012): World Egg Day. - www.fao.org/ag/againfo/home/en/news_archive/2012_World_Egg_Day_2012.html.

[11] Grace, E. J., MacFarlane, G. R. (2016): Assessment of the bioaccumulation of metals to chicken eggs from residential backyards. - Science of the Total Environment 563: 256260.

[12] Hashemi, M., Sadeghi, A., Dankob, M., Aminzare, M., Raeisi, M., Miri, H. H., Saghi, M. (2018): The impact of strain and feed intake on egg toxic trace elements deposition in laying hens and its health risk assessment. - Environmental Monitoring and Assessment 190(9): 540-552. 
[13] Kovacs-Nolan, J., Phillips, M., Mine, Y. (2005): Advances in the value of eggs and egg components for human health. - Journal of Agricultural and Food Chemistry 53(22): 8421-8431.

[14] Kucukkoyuncu, E., Okur, A. A., Tahtabicen, E., Korkmaz, F., Samli, H. E. (2017): Comparing quality of free range and battery cage eggs. - European Poultry Science 81: 17.

[15] Rubio, C., Paz, S., Ojeda, I., Gutiérrez, A. J., González-Weller, D., Hardisson, A., Revert, C. (2017): Dietary intake of metals from fresh cage-reared hens' eggs in Tenerife, Canary Islands. - Journal of Food Quality 2017: 1-11.

[16] Rubio, C., Ojeda, I., Gutierrez, A. J., Paz, S., González-Weller, D., Hardisson, A. (2018): Exposure assessment of trace elements in fresh eggs from free-range and home-grown hens analysed by inductively coupled plasma optical emission spectrometry (ICP-OES). Journal of Food Composition and Analysis 69: 45-52.

[17] Siddiqui, I., Nazami, S. S., Ahmed Khan, F., Bhutto, S., Tahir, M., Munshi, A. B., Syed, N. (2011): Determination of some heavy metals in hen eggs using ICP-AES technique. Pakistan Journal of Biochemistry \& Molecular Biology 44(4): 133-136.

[18] Uluozlu, O. D., Tuzen, M., Mendil, D., Soylak, M. (2009): Assessment of trace element contents of chicken products from Turkey. - Journal of Hazardous Materials 163(2-3): 982-987.

[19] Van Overmeire, I., Pussemier, L., Hanot, V., De Temmerman, L., Hoenig, M., Goeyens, L. (2006): Chemical contamination of free-range eggs from Belgium. - Food Additives and Contaminants 23(11): 1109-1122. 